\title{
ADDITIONAL DISTRIBUTIONAL RECORDS OF SCOLOPENDRID CENTIPEDES (CHILOPODA: SCOLOPENDROMORPHA) FROM KERALA
}

\section{P.M. Sureshan ${ }^{1}$, Vinod Khanna ${ }^{2}$ and C. Radhakrishnan ${ }^{3}$}

${ }^{1}$ Estuarine Biological Station, Zoological Survey of India, Gopalpuron-Sea, Orissa 761002, India

${ }^{2}$ Northern Regional Station, Zoological Survey of India, Dehradun, Uttaranchal 248195, India

${ }^{3}$ Western Ghats Field Research Station, Zoological Survey of India, Calicut, Kerala 673002, India

Email: ${ }^{1}$ samanyu2003@yahoo.com

Sureshan et al. (2004) inventoried and illustrated 15 species of scolopendrid centipedes occurring in Kerala and adjacent areas in the neighboring states, along with a key to their identification. The present study is based on a collection of centipedes available in the Western Ghats Field Research Station, Zoological Survey of India (WGFRS, ZSI), Kozhikode, which includes eight species being recorded here for the first time from Kerala. Accordingly, a total of 23 species of scolopendrid centipedes belonging to eight genera under two subfamilies are now known to occur in Kerala, which forms about $23 \%$ of the centipede fauna of India, in turn roughly comprises $16.5 \%$ of the global diversity (Khanna, 2003). The tropical rainforests of Western Ghats in Kerala provide suitable habitat conditions for rich centipede diversity. However, information of the centipede fauna from this part of the country is poorly documented due to lack of serious field studies and lack of systematic collections. The collections pertaining to the present study are deposited in WGFRS, ZSI, Kozhikode.

List of scolopendrid centipedes occurring in Kerala (* New record from Kerala, **Endemic to Kerala, ${ }^{*}$ Probably occurring in Kerala)

1. Scolopendra amazonica Bucherl, 1946

2. Scolopendra hardwickei Newport, $1844^{+}$

3. Scolopendra morsitans Linnaeus, 1758

4. Scolopendra subspinipes dehaani Brandt, 1840

5. Arthrorhabdus jonesii Verhoeff, 1937 **

6. Cormocephalus dentipes Pocock, 1891 *

7. Cormocephalus nigrificatus Verhoeff, $1937^{* *}$

8. Asanada indica Jangi \& Dass, 1984

9. Asanada socotrana Pocock, 1899

10. Asanada sukhensis Jangi \& Dass, 1984

11. Otostigmus politus poiltus Karsh, 1881

12. Otostigmus splendens Pocock, 1890 *

13. Ethmostigmus coonooranus Chamberlin, 1920 *

14. Ethmostigmus platycephalus platycephalus (Newport, 1845)

15. Digitipes gravelyi Jangi \& Dass, $1984 * *$

16. Digitipes coonorensis Jangi \& Dass, $1984 *$

17. Digitipes barnabasi Jamgi \& Dass, $1984 *$

18. Digitipes chhotanii Jangi \& Dass, 1984
19. Digitipes indicus Jangi \& Dass, 1984

20. Rhysida lithobioides paucidens Pocock, 1897 *

21. Rhysida lithobioides trispinosus Jangi \& Dass, 1984 *

22. Rhysida nuda subnuda Jangi, 1955

23. Rhysida longipes longipes (Newport, 1845)

Systematic account

Class: Chilopoda

Order: Scolopendromorpha

Family: Scolopendridae

Subfamily: Scolopendrinae

Tribe: Scolopendrini

\section{Scolopendra amazonica (Bucherl)}

1946. Scolopendra morsitans amazonica Bucherl. W. Mem. Inst. Butantan, 19. 135-137.

1984. Scolopendra amazonica (Bucherl). Jangi \& Dass. J. Scient. Indl. Res., 43(2): 29.

2001. Scolopendra amazonica (Bucherl). Khanna. Ann. For. 9(2): 201.

Diagnostic characters: Body elongate, flat, with 21 pairs of legs spiracles triangular, cephalic plate overlapping the first tergite, $20^{\text {th }}$ pair of legs without tarsal spur, prefemur of anal legs ventrally with nine spines arranged in three rows of three each.

Distribution: Cosmopolitan.

Material examined: 1ex. Chambakadu, Chinnar Wildlife sanctuary, Idukki district, Kerala. 19.ix.1996, coll. P.M. Sureshan (Reg. No. 9453); 1ex. Kalpetta, Wynad district, 15.xii.1982, 1 ex. Karipur, Malappruam district, 26.vii.1982, 1 ex. Menanyam, Kozhikode district, 10.ii.1983, coll. K.N. Nair and party (Reg. Nos. 1302, 717, 1560); 4exs. Kolamkunnu, Shendurni WLS, Quilon district, 17.viii.1997 (Reg. No. 10673); 1 ex. Palarauvi, Quilon district, 10.viii.1997 (Reg. No. 10645), coll. P.M. Sureshan.

Remarks: It is a medium-sized and the most dominant species of Scolopendra in Deccan. The species is found commonly occurring throughout Kerala. Collected and studied during this project.

\section{Scolopendra hardwickei Newport}

1844. Scolopendra hardwickei Newport. Ann. Nat. Hist., 13: 96. 1903. Scolopendra subspinipes var. hardwickei, Kraepelin, Mitt. Mus., Hamburg, 20: 262.

2001. Scolopendra hardwickei Newport. Khanna. Ann. For. 9(2): 201.

Diagnostic characters: Large and robust species; alternate dark green and brownish-yellow tergal segments giving remarkably a banded appearance to the trunk; anal leg prefemur without spines ventrally. Distribution: India: Andaman \& Nicobar Islands, Andhra Pradesh, Karnataka, Maharashtra, Tamil Nadu and West Bengal.

Remarks: It is the largest and comparatively rare species of scolopendridae in the Deccan. Though not yet reported from Kerala, the species is included here owing to its recent reports from localities bordering the states of Kerala and Tamil Nadu (Rathinasabapathy \& Daniel, 1997; Rathinasabapathy \& Yadav, 2000).

\section{Scolopendra morsitans Linnaeus}

1758. Scolopendra morsitans Linnaeus Syst.Nat., 10. 638.

1984. Scolopendra morsitans Linaeus: Jangi \& Dass. J. Scient. Indl. Res., 43(2): 27-54.

2001. Scolopendra morsitans Linn. Khanna. Ann. For. 9(2): 200. Diagnostic characters: Large and robust species; $20^{\text {th }}$ pair of legs with tarsal spur; anal leg prefemur with three longitudinal rows of three spines on ventral side.

Distribution: Cosmopolitan.

Remarks: It is a large sized species, and is the most dominant species in the Indo-gangetic plains. Khanna (2001) mentioned its occurrence in Kerala. But the present collection contains no specimens of this species. Rathinasabapahty and Yadav (2000) reported this species from Anaikkaty area of Western Ghats. Intensive collection is required 
to ascertain the occurrence of the species in Kerala.

\section{Scolopendra subspinipes dehaani Brandt.}

1840. Scolopendra subspinipes dehaani Brandt. Bull. Ac. St. Petersburg 5:152.

1930. Scolopendra subspinipes dehaani Attems, Das Tierr., Scolopendromorpha 54(2): 51.

2001. Scolopendra subspinipes dehaani Brandt. Khanna. Ann. For. 9(2): 200.

Diagnostic characters: Antennae 18-19 articles, six basal glabrous and rest pilose; cephalic plate punctate and more or less roundish; tergites 1, 2 and 21 without longitudinal sutures and 3-5 and 20 with a pair of incomplete and 6-19 with complete paramedian longitudinal sutures; coxopleural process tipped with two spines, legs 1-20 with one tarsal spur, $21^{\text {st }}$ without tarsal spur.

Distribution: India: Assam, Andaman \& Nicobar Islands, Karnataka, Kerala.

Remarks: Though it is said to be the most abundant species of Scolopendra in the tropical and subtropical lands, it is poorly known from Deccan (Jangi \& Dass, 1984). Khanna (2001) mentioned the occurrence of this species in Kerala but no locality details are available.

\section{Arthrorhabdus jonesii (Verhoeff)}

1937. Arthrorhabdus (Tachycormocephalus) jonesii, Verhoeff Zool. Jahrb. (Syst.) 71: 384.

2001. Arthrorhabdus jonesii Verhoeff. Khanna. Ann. For. 9(2): 203. Diagnostic characters: Cephalic plate without basal plates and without longitudinal sutures; antennae with 17 articles, three basals glabrous and rest pilose; $21^{\text {st }}$ tergite without median suture, lateral margination from $10^{\text {th }}$ onwards, coxopleural process tipped with two spines; 1-4 legs with two tarsal spurs, anal leg prefemur with 1-2 spines ventromedially and three ventrally.

Distribution: India: Kerala: Trivandrum district (Ponmudi).

Remarks: This is a rare species known only from Kerala.

\section{Cormocephalus dentipes Pocock}

1891. Cormocephalus dentipes Pocock. Ann. Nat. Hist. Soc. 6,7: 66. 1984. Cormocephalus pseudonudipes, Jangi \& Dass, J. Scient. Indl. Res., 43(2): 37.

2001. Cormocephalus dentipes Pocock. Khanna. Ann. For. 9(2): 203.

Diagnostic characters: All legs without tarsal spur; $21^{\text {st }}$ tergite without a longitudinal median sulcus, lateral margination present on tergites anterior to $21^{\text {st }}$, maxillipedes with prefemoral process, anal legs in adult male tuberculate.

Material examined: 1ex. Karimala, Parambikulam Wildlife Sanctuary, Palghat district, 27.i.1997, coll. P.M. Sureshan (Reg. No. 9872).

Distribution: India: Madhya Pradesh, Orissa, Kerala, W. Bengal, Uttar Pradesh, Andaman \& Nicobar Islands, Bihar, Delhi, Himachal Pradesh, Meghalaya, Mizoram and Uttaranchal.

Remarks: The species is endemic to India; reported here for the first time from Kerala. Collected and studied during this project.

\section{Cormocephalus nigrificatus Verhoeff.}

1937. Cormocephalus (Dehanonyx) nigrificatus Verhoeff. Zool. Anz. Leipzig 120: 81.

2001. Cormocephalus nigrificatus Verhoeff. Khanna. Ann. For. 9(2): 204.

Diagnostic characters: $21^{\text {st }}$ tergite without a median longitudinal sulcus; lateral margination absent on tergites anterior to 21 ; maxillipedes without prefemoral process.

Material examined: 1ex. Chambakadu, Chinnar WLS, Idukki district, 19.ix.1996, (Reg. No. 9453); 1ex. Kaduvapallam, Quilon district, 11.viii.1997 (Reg. No. 10643), coll. P.M. Sureshan.

Distribution: India: Kerala.

Remarks: The species is known only from Kerala. Apart from the type locality (Nedumangad, Trivandrum District), it is being reported from Quilon and Idukkki districts of Kerala. Collected and studied during this project.
Tribe: Asanadini.

\section{Asanada indica Jangi \& Dass.}

1984. Asanada indica Jangi \& Dass, J. Scient. Indl. Res., 43(2): 3839.

2001. Asanada indica Jangi \& Dass, Khanna. Ann. For. 9(2): 205. Diagnostic characters: Longitudinal median groove present on posterior half of anal leg prefemur and femur; $21^{\text {st }}$ sternite nearly twice as broad as long, posteriorly narrowing, slightly arched and with a slight median notch at posterior margin.

Distribution: India: Kerala, Maharashtra, Orissa, Delhi, Haryana, Rajasthan, Himachal Pradesh, Uttar Pradesh and Uttaranchal.

Remarks: Khanna (2001) mentioned the occurrence of the species in Kerala; no locality details are available. Collected and studied during this project.

\section{Asanada socotrana Pocock.}

1899. Asanada socotrana, Pocock Bull. Liverpool Mus., 2: 9.

1918. Asanada brevicornis Var. afra, Silvestri, Boll. Laborat. Zool. Portici., 12: 311.

1930. Asanada socotrana, Attems, Das Tierr., Scolopendromorpha, 54(2): 124-125.

2001. Asanada socotrana Pocock, Khanna. Ann. For. 9(2): 205.

Diagnostic characters: Anal legs short and thick; paired longitudinal median sutures always complete on $20^{\text {th }}$ tergite; $21^{\text {st }}$ tergite more than twice as broad as long; longitudinal median groove present throughout on anal leg femur only.

Distribution: India: Kerala, Maharashtra, Tamil Nadu.

Remarks: Jangi and Dass (1984) reported this species from Parambikulam of Palghat district.

\section{Asanada sukhensis Jangi \& Dass.}

1984. Asanada sukhensis Jangi \& Dass. J. Scient. Indl. Res., 43(2): 38-39.

2001. Asanada sukhensis Jangi \& Dass. Khanna. Ann. For. 9(2): 205.

Diagnostic characters: Anal legs short and thick; $21^{\text {st }}$ tergite more than twice as broad as long; longitudinal median groove confined to posterior half of anal leg femur only.

Distribution: India: Kerala, Madhya Pradesh, Orissa.

Remarks: This species is endemic to India. Khanna (2001) mentioned the occurrence of the species from Kerala; no locality details are available.

\section{Subfamily: Otostigminae}

Tribe: Otostigmini

11. Otostigmus politus politus Karsch.

1881. Otostigma politum, Karsch, Berlin Ent. Z., 25: 219.

1930. Otostigmus (O) politus politus Attems, Das Tierr., Scolopendromorpha, 54(2): 149

2001. Otostigmus politus politus Karsch. Khanna. Ann. For. 9(2): 207.

Diagnostic characters: Claw of second maxillae with a spur; first 56 legs with two tarsal spurs and following legs up to $19^{\text {th }}$ with a single tarsal spur; tergites smooth.

Distribution: India: Assam, Delhi, Himachal Pradesh, Kerala, Maharashtra, Meghalaya, Orissa, Sikkim, Uttaranchal and West Bengal.

Remarks: Khanna (2001) mentioned the occurrence of this species from Kerala; no locality details are available. It is an uncommon species.

\section{Otostigmus splendens Pocock.}

1890. Otostigmus splendens, Pocock. Ann. Nat. Hist., Ser., 6,5: 245.

1930. Otostigmus (O) splendens, Attems. Das Tierr., Scolopendromorpha 54(2): 145.

2001. Otostigmus splendens Pocock. Khanna. Ann. For. 9(2): 206.

Diagnostic characters: Coxopleural process with dorsal spine; anal legs with prefemoral process. 
Material examined: 1 ex. Parakkadavu, Shendurni Wildlife Sanctuary, Quilon district; 8.viii.1997 (Reg. No. 10463); 1 ex. Vallamvetti, Quilon district, 18.viii.1997 (Reg. No. 10465), coll. P.M. Sureshan.

Distribution: India: Kerala, Maharashtra and Tamil Nadu.

Remarks: The species is reported here for the first time from Kerala. Collected and studied during this project.

\section{Ethmostigmus coonooranus Chamberlin.}

1920. Ethmostigmus coonooranus, Chamberlin,. Univ. Calif. Pub. 19: 392.

1930. Ethmostigmus coonooranus Attems. Das Tierr., Scolopendromorpha 54(2): 178.

2001. Ethmostigmus coonooranus Chamberlin. Khanna. Ann. For. 9(2): 209.

Diagnostic characters: First pair of spiracles large and sieve like; prefemur of maxillipedes without a median dental process; three basal antennal segments glabrous.

Material examined: 6 exs. Vallamvetti, Quilon district, 18.viii.1997 (Reg. No. 10465); 1 ex. Kaduvapallam, Quilon district, 11.viii.1997 ( Reg. No. 10463), coll. P.M. Sureshan.

Distribution: India: Tamil Nadu, Kerala.

Remarks: The species has been so far known only from Nilgiri district, Tamil Nadu. It is reported here for the first time from Kerala. Collected and studied during this project.

14. Ethmostigmus platycephalus platycephalus (Newport). 1845. Heterostoma platycephalus platycephalus, Newport, Trans. Linn. Soc. 19:415.

1903. Ethmostigmus platycephalus Kraepelin,. Mitt. Mus., Hamburg, 20: 162.

1930. Ethmostigmus platycephalus platycephalus Attems. Das Tierr., Scolopendromorpha 54(2): 18.

2001. Ethmostigmus platycephlaus platycephalus (Newport). Khanna. Ann. For. 9(2): 209.

Diagnostic characters: Four basal antennal segments glabrous; anal leg prefemur mostly with three ventrolateral spines; coxopleural process tipped with 2-4 spines and bearing dorsally 0-1 spines.

Material examined: 1 ex.Kurichiad, Wynad dist., 1.ii.1983, coll. K.N. Nair (Reg. No.3151); 1 ex, Kottawasal, Aryankavu, Quilon dist., 15.viii.1997 (Reg. No.10678); 1 ex. Thannikudi, Periyar Tiger Reserve, Idukki dist, 7.xi.1996 (Reg.No.9452); 6 exs. Manakavala, Periyar Tiger Reserve, Idukki dist., 12.xi.1996 (Reg. No. 9455); 1 ex. Pooyamkutty, Pindimedu, Ernakulam dist. 24.xi.1999 (Reg. No. 10019); 2exs. Vallamvetti, Quilon dist., 18.viii. 1997 (Reg. No. 10465); 2 exs. Palaruvi, Quilon dist., 10.viii.1997 (Reg. No. 10645); coll. P.M. Sureshan.

Distribution: India: Kerala, Maharashtra.

Remarks: The species is locally common in the forested tracts of Western Ghats in Kerala. The specimens from the area are robust and dark brown in colour. Collected and studied during this project.

\section{Digitipes gravelyi Jangi \& Dass}

1984. Digitipes gravelyi Jangi \& Dass. Scient. Indl. Res. 43(2): 41. 2001. Digitipes gravelyi Jangi \& Dass. Khanna. Ann. For. 9(2): 210. Diagnostic characters: Tergites beyond 1 and 2 ridgy and tuberculate; paramedian sutures complete on 6-20, confined anteriorly and posteriorly on preceding ones; coxopleural process tipped with four spines and bearing two lateral spines.

Material examined: 1 ex. Palaruvi, Quilon dist., 10.viii.1997 (Reg. No.10645); 1 ex, Vallamvetti, Quilon dist., 18.viii.1997 (Reg. No.10465); 1 ex. Parakkadavu, Shendurni Wildlife Sanctuary, Quilon dist., 8.viii.1997 (Reg. No.10463), coll. P.M. Sureshan.

Distribution: India: Kerala.

Remarks: The species is endemic to Kerala and has been described from Parambikulam of Palghat district. Here the species is reported from Quilon district subsequent to its original description. Collected and studied during this project.

16. Digitipes coonoorensis Jangi \& Dass.

1984. Digitipes coonoorensis Jangi \& Dass, Scient. Indl. Res., 43(2):
43.

2001. Digitipes coonoorensis Jangi \& Dass. Khanna. Ann. For. 9(2): 210.

Diagnostic characters: $20^{\text {th }}$ leg without tarsal spur; $21^{\text {st }}$ tergite a little broader than long and having its lateral margins slightly convex; coxopleural process tipped with two spines and bearing a single lateral spine.

Material examined: 2exs. Rajakoop, Shendurni WLS, Quilon dist., 14.viii.1997 (Reg.No10476); 1ex. Kaladi, Kodanad, Mallana, Ernakulam dist., 12.xi.1999 (Reg. No. 11263); 2exs. Pooyamkutty, Pindimedu, Ernakulam dist. 22.xi.1999 (Reg. No.11260); 2exs. Kottiyoor, Kannur dist., 2.ii.1995 (Reg. No. 7453); 4exs. Kazhuthurutty, Shendurni WLS, Quilon dist. 9.viii.1997 (Reg. No. 10462); 1ex. Parakkadavu, Shendurni WLS, Quilon dist 8.viii.1997 (Reg. No. 10465), coll. P.M. Sureshan.

Distribution: India: Kerala, Maharashtra, Tamil Nadu.

Remarks: This species was known only from Tamil Nadu and Maharashtra. Here the species is reported for the first time from Kerala. The species appears locally common in the forested tracts of Kerala. Collected and studied during this project.

\section{Digitipes barnabasi Jangi \& Dass.}

1984. Digitipes barnabasi Jangi \& Dass. Scient. Indl. Res., 43(2): 44.

2001. Digitipes barnabasi Jangi \& Dass. Khanna. Ann. For. 9(2): 210.

Diagnostic characters: $20^{\text {th }}$ leg with tarsal spur; porous area of coxopleura almost touching dorsal margins.

Material examined: 1ex. Kottiyoor, Kannur dist. 31.i.1995 (Reg. No. 7448), coll. P.M.Sureshan.

Distribution: India: Kerala, Maharashtra,Tamil Nadu.

Remarks: This species was known only from Tamil Nadu and Maharashtra. Here the species is reported for the first time from Kerala. Collected and studied during this project.

\section{Digitipes chhotanii Jangi \& Dass.}

1984. Digitipes chhotanii Jangi \& Dass,. Scient. Indl. Res., 43(2): 46.

2001. Digitipes chhotanii Jangi \& Dass. Khanna. Ann. For. 9(2): 210. Diagnostic characters: $20^{\text {th }}$ leg without tarsal spur; lateral tergital margination beginning on $7^{\text {th }}$; posterior margin of $21^{\text {st }}$ sternite straight; $1^{\text {st }}$ tarsus of anal leg nearly twice as long as second, $2^{\text {nd }}$ tarsus 3.5 times as long as claw.

Material examined: 2exs. Thakarappady, Kozhikode dist.15.x.1991, (Reg. No. 113), coll. K.N. Nair \& party; 1ex. Kottiyoor, Kannur dist., 2.ii.1995 (Reg. No.7453); 1ex. Amakulam, Kulathupuzha, Quilon dist., 16.viii.1997 (Reg. No.10464); 2exs. Chambakad, Chinnar WLS, Idukki dist., 18.xi.1996 (Reg. No. 9459), coll. P.M. Sureshan.

Distribution: India: Kerala, Maharashtra,. Tamil Nadu.

Remarks: According to Khanna (2001) the species is known from Kerala. Collected and studied during this project.

\section{Digitipes indicus Jangi \& Dass.}

1984. Digitipes indicus Jangi \& Dass. Scient. Indl. Res., 43(2): 4647.

2001. Digitipes indicus Jangi \& Dass. Khanna. Ann. For. 9(2): 210. Diagnostic characters: $20^{\text {th }}$ leg with tarsal spur; lateral margination beginning on $11^{\text {th }}$ leg bearing segment; posterior margin of $21^{\text {st }}$ sternite concave; $1^{\text {st }}$ tarsus of anal leg nearly 1.5 times as long as $2^{\text {nd }}$ and $2^{\text {nd }}$ tarsus slightly more than twice as long as claw; prefemoral spines of anal leg comprising a ventrolateral and a ventromedial spine.

Material examined: 1ex. Menanyam, Kozikode dist.10.ii.1983 (Reg. No.1560), coll. K.N. Nair \& party; 1ex. Kaduvapallam, Quilond dist., 2.viii.1997 (Reg. No. 10643); 1ex. Palaruvi, Quilon dist., 10.viii.1997 (Reg. No. 10645), coll. P.M. Sureshan.

Distribution: India: Kerala, Maharashtra.

Remarks: This species is described from Kerala based on the specimen collected from Palghat district. The species is also reported from Trichur district of Kerala (Jangi \& Dass, 1984). Collected and studied during this project. 


\section{Rhysida lithobioides paucidens Pocock}

1897. Rhysida paucidens, Pocock, D. Smith, Unknown African countries, app.c,p. 403.

1930. Rhysida lithobioides paucidens, Attems, Das Tierr., Scolopendromorpha, 54(2): 188.

2001. Rhysida lithobioides paucidens Pocock. Khanna. Ann. For. 9(2): 211.

Diagnostic characters: Coxopleural process without lateral spines; sternites with anteriorly confined short suture; first eight or more pairs of legs with two tarsal spurs; coxopleural process tipped with two spines; $21^{\text {st }}$ sternite hardly tapering posteriorly.

Material examined: 1ex. Kottavasal, Aryankavu, Quilon dist., 15.viii.1997 (Reg. No. 10678), coll. P.M.Sureshan.

Distribution: India: Kerala, Pondicherry, Tamil Nadu.

Remarks: This is a species endemic to Deccan. The species is reported here for the first time from Kerala. Collected and studied during this project.

\section{Rhysida lithobioides trispinosus Jangi \& Dass.}

1984. Rhysida lithobioides trispinosus, Jangi \& Dass. J. Scient. Indl. Res., 43(2):48.

2001. Rhysida lithobioides trispinosus Jangi \& Dass. Khanna. Ann. For. 9(2): 211.

Diagnostic characters: Coxopleural process tipped with three spines; $21^{\text {st }}$ sternite clearly tapering posteriorly; sternites with short paramedian sulci confined anteriorly; $21^{\text {st }}$ tapering caudad and with prominently convex lateral margins and concave posterior margin. Material examined: 1ex. Kattilappara, Shendurni WLS, Quilon dist., 12.viii.1997 (Reg. No. 10675); 1ex. Kolamkunnu, Shendurni WLS, Quilon dist., 17.viii.1997 (Reg. No. 10673); 1ex. Pooyamkutty. Pindimedu, Ernakulam dist., 24.xi.1999, (Reg. no. 10019); 7exs. Chambakad, Chinnar Wild life sanctuary, Idukki dist., 18.xi.1996 (Reg. No. 9459), 1ex. Karimala, Parambikulam WLS, Palghat dist., 27.i.1997 (Reg. No. 9872), coll. P.M. Sureshan.

Distribution: India: Kerala, Tamil Nadu, Maharashtra.

Remarks: This is a species endemic to the Deccan and is reported here for the first time from Kerala. The species is locally common in the forested tracts of Kerala. Collected and studied during this project.

\section{2. "Rhysida nuda subnuda Jangi}

1955. Rhysida nuda subnuda, Jangi. Ann. Mag. nat. Hist. ser. 12,8: 69-80.

2001. Rhysida nuda subnuda Jangi. Khanna. Ann. For. 9(2): 212.

Diagnostic characters: Only $21^{\text {st }}$ tergite laterally marginate, $20^{\text {th }}$ pair of legs with one tarsal spur; apex of the coxopleural processs without spines; antennae 21 segmented.

Material examined: 3exs., Koduvally, Kozhikode dist., 21.ix.1982 (Reg. No. 1056, 1057), coll. K.N. Nair \& party; 3exs. Kottavasal, Aryankavu, Quilon dist.,15.viii.1997 (Reg. No. 10678), 1ex. Kattilappara, Quilon dist., 12.viii.1997 (Reg. No. 10675), 12exs. Kolamkunnu, Quilon dist., 17.viii.1997 (Reg. No. 10673), 3exs. Manjappara, Pooyamkutty,
Ernakulam dist., 15.xi.1999 (Reg. No. 10999); 3exs. Kazhuthurutty, Thenmala, Quilon dist., 9.viii.1997 (Reg. No. 10462); 1ex. Karimala, Parambikulam WLS, Palghat dist., 29.iii.1997 (Reg. No. 10078); 3exs. Kaduvapallam, Quilon dist., 11.viii.1997, (Reg. No. 10643), coll. P.M. Sureshan.

Distribution: Cosmopolitan.

Remarks: This is a common species occurring throughout Kerala.

\section{Rhysida longipes longipes (Newport).}

1845. Branchiostoma longipes longipes, Newport. Trans. Linn. Soc., London. 19: 411.

1930. Rhysida longipes, Attems. Das Tierr., Scolopendromorpha, 54(2): 194.

2001. Rhysida longipes longipes (Newport). Khanna. Ann. For. 9(2): 212.

Diagnostic characters: Prefemur of anal leg with posteromedial spiny process; coxopleural process with lateral spine; tergites preceding $21^{\text {st }}$ clearly marginate laterally and several of them involved.

Material examined: 1ex. Kottavasal, Aryankavu, Quilon dist., 15.viii.1997 (Reg. No. 10678), 2exs. Kattilappara, Quilon dist., 12.viii.1997 (Reg. No. 10675); 9exs., Kolamkunnu, Quilon dist., 17.viii.1997 (Reg. No. 10673), coll. P.M. Sureshan.

Distribution: India: Andaman \& Nicobar Islands, Arunachal Pradesh, Delhi, Goa, Karnataka, Kerala, Madhya Pradesh, Maharashtra, Uttaranchal, Uttar Pradesh, W. Bengal,

Remarks: This is a commonly occurring Rhysida species. It is reported here for the first time from Kerala. Collected and studied during this project.

\section{Discussion}

The family Scolopendridae is represented in Kerala by 22 species belonging to eight genera, viz., Scolopendra, Arthrorhabdus, Cormocephalus, Asanada, Digitipes, Otostigmus, Ethmostigmus and Rhysida. Of these, the first four belong to the subfamily Scolopendrinae and the remaining four to the subfamily Otostigminae. The genus Scolopendra found throughout the tropics and the warmer lands of temperate world is unique in having the cephalic plate, which clearly overlies the anterior margin of the first tergite. Among the 21 species of Indian Scolopendra, only two are so far known from Kerala, namely, S. amazonica and S. morsitans. These two species are sympatric and cosmopolitan in distribution, which were considered earlier conspecific. The most important distinguishing character between these two species is the spur on $20^{\text {th }} \mathrm{leg}$, which is present in morsitans and absent in amazonica. Though there is an opinion among workers favouring the synonymy of these species, Jangi and Dass (1984)

\section{Key to the Rhysida species of Kerala}

1. Only $21^{\text {st }}$ tergite laterally marginate, and if at all hardly a couple of them preceding $21^{\text {st }}$ marginate, that too incompletely and weakly... Rhysida nuda (Newport) $\left(20^{\text {th }}\right.$ pair of walking legs without tarsal spur; coxopleural process without spines; antenna 21 segmented) .............................................. sub species subnuda Jangi

-- $\quad$ Tergites preceding $21^{\text {st }}$ clearly marginate laterally and several of them involved Coxopleural process with lateral spine ............... Rhysida longipes (Newport) (prefemur of anal leg with
posteriomedial spiny processs ........................................................... subspecies longipes (Newport) Coxopleural process without lateral spine (sternites at the most with anteriorly confined short suture; first 8 or more pairs of legs with 2 tarsal spurs Rhysida lithobioides (Newport) .............

3. Coxopleural process tipped with 2 spines, seldom with 1 spine; $21^{\text {st }}$ sternite hardly tapering posteriorly ......... ............................................................................................ Rhysida lithobioides paucidens Pocock Coxopleural process tipped with 3 spines, $21^{\text {st }}$ sternite clearly tapering posteriorly 
clearly mentioned their separate status in the Deccan. Though the most dominant species of Indo-Gangetic plains, $S$. morsitans is very rarely reported from Tamil Nadu, Karnataka and Kerala, the species is not represented in the present collection. Jangi and Dass (1984) expressed the view that the records of $S$. morsitans from these three states may be pertaining to S. amazonica. Rathinasabapathy and Yadav (2000) reported this species from Anaikatty area of Western Ghats, Tamil Nadu. S. hardwickei Newport is another rare Scolopendra species not reported from Kerala but known from localities bordering Kerala and Tamil Nadu (Rathinasabapathy \& Yadav, 2000). So intensive field exploration and collection of specimens throughout Kerala is essential to prove the occurrence of $S$. morsitans and $S$. hardwickei in the state.

Scolopendra subspinipes dehaani Brandt is another Scolopendra species known from Kerala (Khanna, 2001). The occurrence of this species in Kerala is doubtful and the above record may pertain to that from Karwar district of Karnataka by Jangi and Dass (1984). Another interesting species of Scolopendrini is Arthrorhabdus jonesii, which is the only representative of the genus in India. The species is known only form the Ponmudi hills of Trivandrum district. It is very essential to make intensive collection of centipedes from this area in order to prove the occurrence of the species still in that locality after a gap of several years since its earlier report. Cormocephalus is a genus of Scolopendrinae, which is species-rich. Out of the eight Indian species, only two are represented in Kerala, namely, $C$. nigrificatus and $C$. dentipes. Both these species lack a longitudinal median sulcus on the $21^{\text {st }}$ tergite, which separate them from other Indian species. C. nigrificatus is so far known only from the Thiruvananthapuram district of Kerala, its distribution is extended here to Idukki and Quilon districts by the collection of specimens.

Asanadini is a monogeneric tribe with the genus Asanada. Though the genus has an extensive geographical range, it is very poorly represented in general collections. Among the eight species known from India, three are represented in Kerala viz., $A$. indicus, A. socotrana, and A. sukhensis. All these species have short and thick anal legs unlike in other Indian species with anal legs long and slender. Not a single specimen of Asanada is represented in the present collection. Since members of this genus are usually smaller in size and unnoticeable, special care has to be taken during collection.

The subfamily Otostigminae is represented by 13 species from Kerala, among them Digitipes contains five, followed by Rhysida with four and Ethmostigmus and Otostigmus each with two species. Digitipes coonoorensis is represented by a good number of

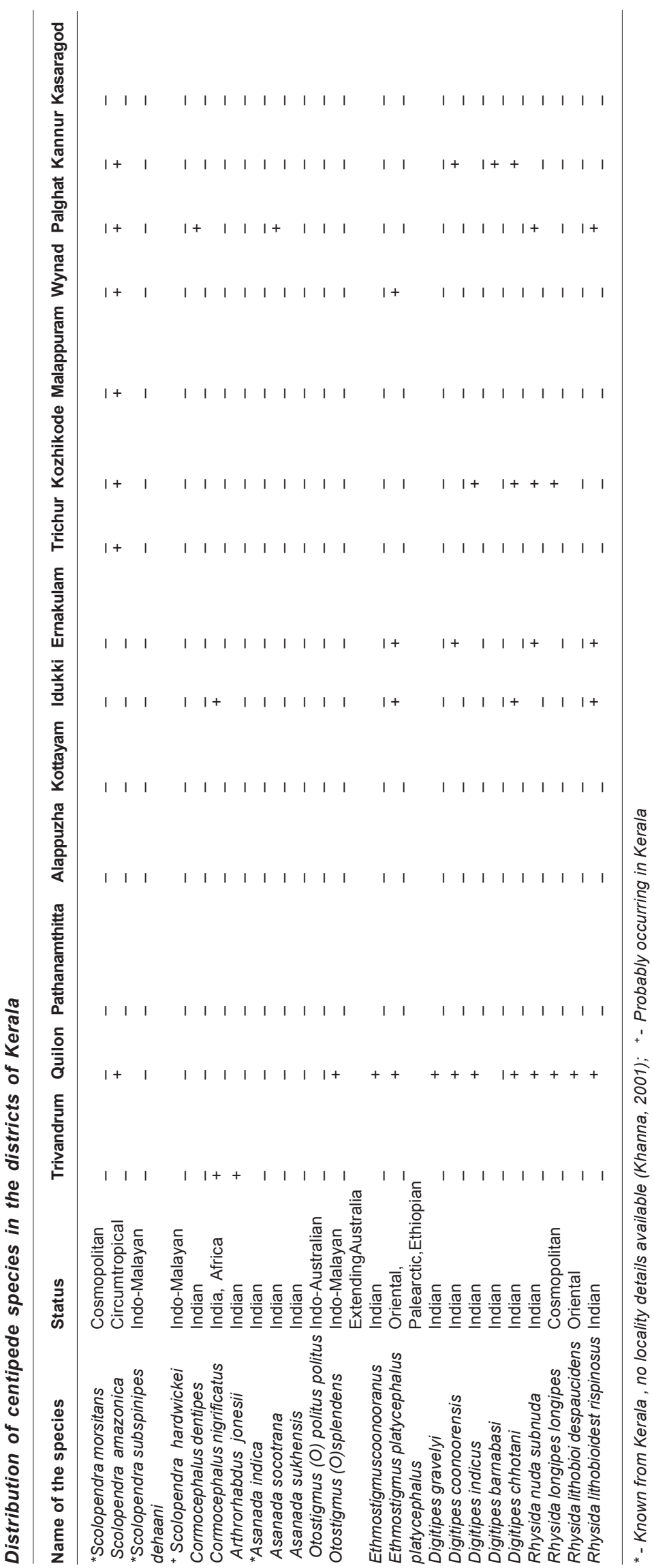

June 2006 Zoos' Print Journal 21(6): 2285-2291 


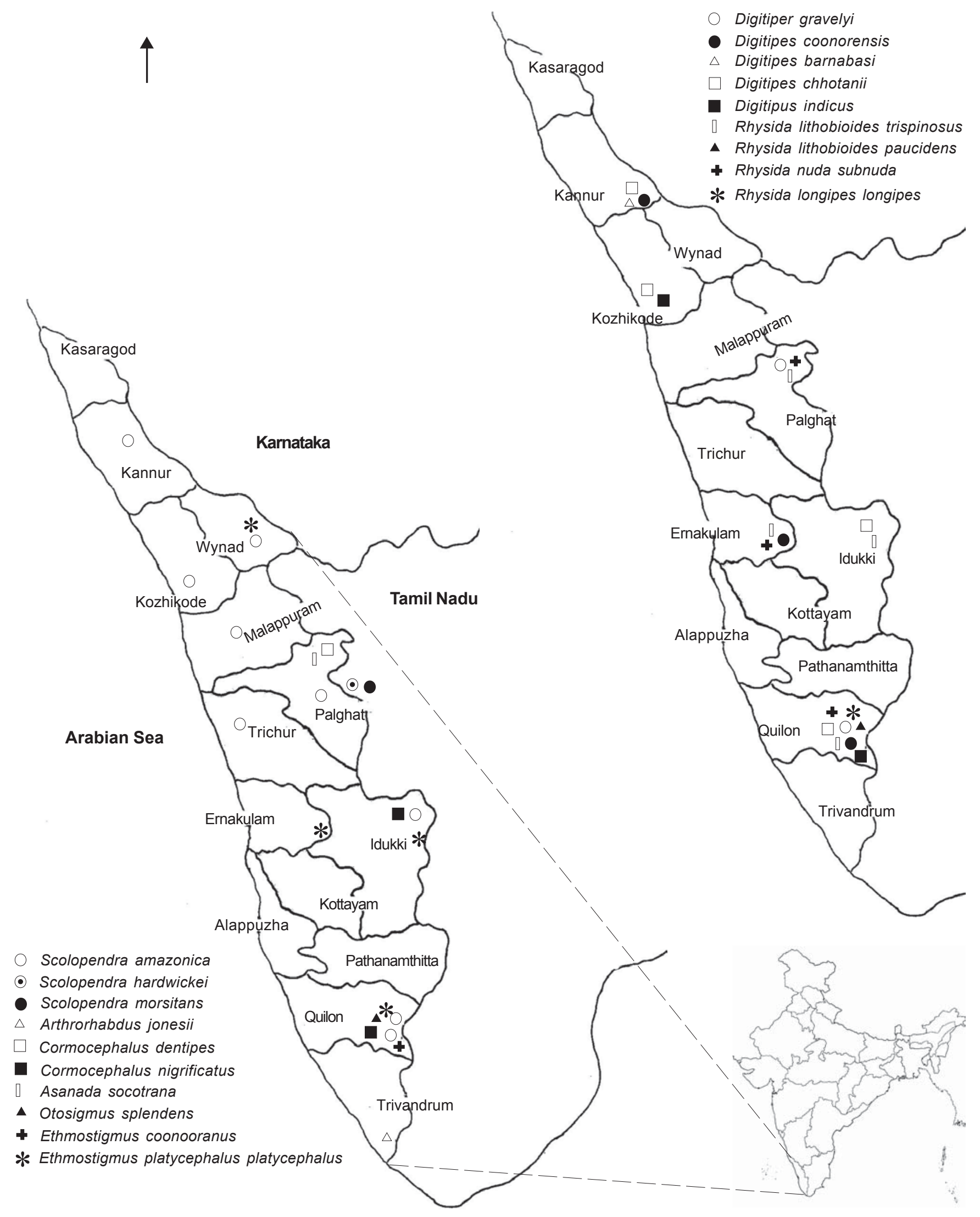

Figure 1. Maps showing distribution of centipedes in Kerala 
specimens in the collection, mostly collected from the forested tracts of Western Ghats. It is reported for the first time from Kerala. Occurrence of Digitipes barnabasi in Western Ghats of Kerala is interesting since it is previously known only from Maharashtra and Tamil Nadu (Yadav 2001; Khanna, 2001). The other species of Digitipes known from Kerala are $D$. indicus, $D$. gravelyi and D. chhotani, which are all represented in the Deccan too.

The genus Otostigmus is species rich as far as India is concerned. According to Khanna (2001), 23 species of Otostigmus are known from India. Though species rich, the genus is also not plentiful in the collections; only two specimens of $O$. splendens are encountered here collected from Quilon district. O. politus politus is also known from the state. In Ethmostigmus, E. platycephalus platycephalus is found commonly occurring in the forested tracts of Kerala represented by specimens of robust size. E. coonooranus is reported here for the first time from Kerala. The genus Rhysida is represented by four species, viz., R. nuda subnuda, R. lithobioides trispinosus, $R$. lithobioides paucidens and $R$. longipes longipes. Among these, R. nuda subnuda is found commonly occurring in both the plains and hills of Kerala represented by maximum number of specimens in the collection. The occurrence of $R$. lithobioides paucidens in Kerala is also interesting.

The present study proved that the centipede fauna of Kerala is rich though not explored fully. They form a rewarding animal group for detailed systematic studies from Kerala since they play a very valuable role in the terrestrial ecosystems acting as important links in the food chains, devouring harmful insect pests, meal worms, termites, millipedes etc thereby helping to control them. Even though the present collection represents a randomly picked assemblage of specimens, it contains some interesting species, which are being reported for the first time from Kerala. Since most the present collection is made from the forested tracts of Western Ghats, it will not give a complete picture of the distribution of the centipede species in Kerala. So more intensive collections of centipedes from the plains and mid lands are also very essential to derive a complete picture of the distribution of centipede fauna in Kerala. Moreover, some of the districts of Kerala like Kasaragod, Alappuzha, Pathanamthitta and Kottayam are totally unexplored for centipedes and there are no records of species available from these districts. Serious attempts to collect centipedes from all the different types of habitats belonging to the 14 districts of Kerala needs to be made to get a clear picture of the distribution, endemism, intraspecific variations, evolutionary status etc of the centipede species occurring in this part of peninsular India, which will in turn provide further detailed knowledge on the centipede fauna of the country.

\section{REFERENCES}

Jangi, B.J. and C.M.S. Dass (1984). Scolopendridae of the Deccan. Journal of Scientific and Industrial Research 43: 27-54.

Khanna, V. (2001). A checklist of the Indian species of the centipedes (Chilopoda: Scolopendromorpha). Annals of Forestry 9(2): 199-219.

Khanna, V. (2003). Diversity of Scolopendrid centipedes (Chilopoda: Scolopendromorpha) in Himalayan ecosystem and adjacent areas - A review. Records of Zoological Survey of India 101(3-4): 207-223. Rathinasabapathy, B. and B.A. Daniel (1997). Note on Tiger Centipede Scolopendra hardwickei (Newport) from Coimbatore Zoological Park site, Anaikatty, Western Ghats. Zoos' Print 12(8): 1.

Rathinasabapathy, B. and B.E. Yadav (2000). Centipedes (Scolopendridae) of Coimbatore Zoological Park Area, Anaikatty, Western Ghats. Zoos' Print Journal 15(19): 327-328.

Sureshan, P.M., B.E. Yadav and C. Radhakrishnan (2003). An illustrated key to the identification of centipedes (Chilopoda: Scolopendromorpha) of Kerala. Zoos' Print Journal 19(3): 1401-1407.

Yadav, B.E. (2001). Centipedes (Chilopoda: Scolopendridae), pp. 3944. In: Fauna of conservation Area Series No.11. Fauna of Nilgiri Biosphere Reserve. Zoological Survey of India, Kolkata.

\section{ACKNOWLEDGEMENTS}

The authors are grateful to Dr. J.R.B. Alfred, Director, Zoological Survey of India, Kolkata and Dr. S.Z. Siddiqi, Officer-in-charge, Zoological Survey of India, Estuarine Biological Station, Gopalpur-on-Sea, Orissa for providing facilities and encouragement. 